\title{
Hepatitis B genotype $G$ and high frequency of lamivudine-resistance mutations among human immunodeficiency virus/hepatitis B virus co-infected patients in Brazil
}

\author{
Adriana Cristina da Silva ${ }^{1,2}$, Ângela Maria Miranda Spina², Marcílio Figueiredo Lemos ${ }^{2}$, \\ Isabel Takano Oba², Cristina de Fátima Guastini', Michele Soares Gomes-Gouvêa ${ }^{3}$, \\ João Renato Rebello Pinho ${ }^{3,4}$, Maria Cássia Jacintho Mendes-Correa ${ }^{1 /+}$
'Departamento de Doenças Infecciosas e Parasitárias, Hospital das Clínicas ${ }^{3}$ Departamento de Gastroenterologia, Laboratório de Gastroenterologia e Hepatologia Tropical, Instituto de Medicina Tropical, Faculdade de Medicina, Universidade de São Paulo, São Paulo, SP, Brasil 2Laboratório de Hepatites Virais, Instituto Adolfo Lutz, São Paulo, SP, Brasil ${ }^{4}$ Departamento de Patologia Clínica, Hospital Israelita Albert Einstein, São Paulo, SP, Brasil

\begin{abstract}
In this study, we evaluated the hepatitis $B$ virus $(H B V)$ genotype distribution and $H B V$ genomic mutations among a group of human immunodeficiency virus-HBV co-infected patients from an AIDS outpatient clinic in São Paulo. HBV serological markers were detected by commercially available enzyme immunoassay kits. HBV DNA was detected using in-house nested polymerase chain reaction and quantified by Cobas Amplicor. HBV genotypes and mutations in the basal core promoter (BCP)/pre-core/core regions and surface/polymerase genes were determined by sequencing. Among the 59 patients included in this study, 55 reported prior use of lamivudine (LAM) or tenofovir. HBV DNA was detected in 16/22 patients, with a genotype distribution of $A(n=12,75 \%), G(n=2,13 \%), D(n=1,6 \%)$ and $F(n=1,6 \%)$. The sequence data of the two patients infected with genotype G strongly suggested co-infection with genotype A. In 10 patients with viremia, LAM-resistance mutations in the polymerase gene (rtL180M $+r t M 204 V$ and rtV173L $+r t L 180 M$ $+r$ M204V) were found, accompanied by changes in the envelope gene (sI195M, sW196L and sI195M/sE164D). Mutations in the BCP and pre-core regions were identified in four patients. In conclusion, genotype $G$, which is rarely seen in Brazil, was observed in the group of patients included in our study. A high prevalence of mutations associated with LAM-resistance and mutations associated with anti-HBs resistance were also found among these patients.
\end{abstract}

Key words: hepatitis B - HIV - genotypes - genotype G - mutation - lamivudine

Chronic hepatitis B virus (HBV) infection is an important public health problem affecting around 360 million people worldwide (Shepard et al. 2006). In Brazil, the prevalence of HBV carriers is difficult to assess because of the size and the cultural and socio-economic diversity of Brazil. The prevalence of the HBsAg was estimated at less than $1 \%$ in the Northeast and CentralWest Regions (Pereira et al. 2009) and around 1\% in the municipality of São Paulo (Focaccia et al. 1998). In the Brazilian Amazon Region, a higher prevalence was estimated to be $3.3-20.6 \%$ in some specific populations, such as certain indigenous groups (Braga et al. 2001, 2005, Tavares-Neto et al. 2004).

Among patients co-infected with the human immunodeficiency virus (HIV), HBV prevalence in Brazil varies from 1.6-8.5\% (Mendes-Correa et al. 2000, Monteiro et al. 2004, Souza et al. 2004, Tovo et al. 2006, Zago et al. 2007, Portelinha Filho et al. 2009). HIV coinfection modifies hepatitis B progression by decreas-

\footnotetext{
Financial support: FAPESP

+Corresponding author: cassiamc@uol.com.br

Received 6 January 2010

Accepted 5 July 2010
}

ing the anti-HBV immune response after acute HBV infection, thereby increasing the risk of chronic infection (Benhamou 2007). Furthermore, higher HBV DNA levels and severe forms of hepatic disease, such as cirrhosis and hepatocellular carcinoma, have been observed in patients with HBV/HIV co-infection (Bonacini et al. 2004, Soriano et al. 2008).

Lamivudine (LAM) is the most common drug utilized for hepatitis B treatment in patients co-infected with HIV, as it inhibits both HIV and HBV viral replication. LAM has a high tolerance and proven efficacy and is part of a highly effective antiretroviral therapy. LAM inhibits HBV replication in up to $86 \%$ of patients coinfected with HIV/HBV. Nevertheless, its prolonged use may result in resistance mutations in the HBV genome. In patients infected with HBV only, resistance to LAM progressively increases at an annual rate of $14-32 \%$ and in patients co-infected with HIV, HBV resistance to LAM can rapidly appear (Benhamou et al. 1999). After four years of continuous use in co-infected patients, HBV resistance to LAM can be detected in up to $90 \%$ of this population (Soriano et al. 2009).

Data on HBV genotype distribution and LAMresistance among HIV co-infected patients are lacking in Brazil (Santos et al. 2004, Sucupira et al. 2006, Bottecchia et al. 2008). Thus, in this study, we evaluated the HBV genotype distribution and presence of clinically relevant HBV mutations among HIV co-infected 
patients receiving treatment in the municipality of São Paulo. The following mutations were studied: (i) LAMresistance-associated mutations in the polymerase gene, (ii) mutations in the overlapping surface antigen gene, (iii) basal core promoter (BCP) mutations and (iv) precore mutations. The presence of these mutations was analyzed in conjunction with HBV genotypes and other selected clinical and demographic variables.

\section{PATIENTS, MATERIALS AND METHODS}

Patients were selected among those regularly followed up by the AIDS Outpatient Clinic of the Clinics Hospital, University of São Paulo School of Medicine (HC-FMUSP), between May 2006-May 2007.

Electronic database search and analysis of medical records - We searched for information about HBsAgreactive patients using an electronic database query and performed a serological profile analysis to identify HBsAg-positive patients under regular treatment during the time frame cited above.

The following clinical and demographic variables were also considered for analysis: gender, age, HIV or HBV risk factors, evidence of advanced hepatic disease, adherence to treatment regimen, antiviral drug use [LAM, tenofovir (TDF), entecavir (ETV) or interferon (IFN)], CD4 ${ }^{+} \mathrm{T}$ cell count, liver enzymes [alanine aminotransferase (ALT), aspartate aminotransferase (AST), gamma-glutamyl transferase (GGT) and alkaline phosphatase (ALP)] and histological alterations in liver biopsies.

Blood collection - After informed consent was obtained from patients that joined the study, a blood sample was collected for HBV serological and molecular biological tests.

Serology - A micro-particle enzyme immunoassay (MEIA) (AxSYM, Abbott Laboratories, Abbott Park, IL, USA) was used to detect hepatitis B serological markers (HBsAg, total anti-HBc, anti-HBs, HBeAg and anti-HBe) at the central laboratory of the HC-FMUSP.

Molecular biology assays - Molecular biology assays were performed at the Laboratory of Viral Hepatitis of the Instituto Adolfo Lutz and at the Laboratory of Tropical Hepatology and Gastroenterology of the Tropical Medicine Institute, Department of Gastroenterology, HC-FMUSP.

HBV DNA detection by nested polymerase chain reaction (PCR) - HBV DNA was detected by nested PCR as previously described (Pinho et al. 1993). Briefly, serum samples $(10 \mu \mathrm{L})$ were denatured with $2.5 \mu \mathrm{L}$ of $0.5 \mathrm{M} \mathrm{NaOH}$ and incubated at $37^{\circ} \mathrm{C}$ for $1 \mathrm{~h}$. Samples were neutralized with $2.5 \mu \mathrm{L}$ of $0.5 \mathrm{M} \mathrm{HCl}$. For the first round, $1 \mu \mathrm{M}$ of each primer (1763 and 2032R) was added to the mixture. Amplification was carried out by 25 cycles at $94^{\circ} \mathrm{C}$ for $1 \mathrm{~min}, 42^{\circ} \mathrm{C}$ for $1 \mathrm{~min}$ and $72^{\circ} \mathrm{C}$ for $2 \mathrm{~min}$, followed by an extension step at $72^{\circ} \mathrm{C}$ for $5 \mathrm{~min}$. In the second round, a 1:10 dilution of the first round product was amplified by primers 1778 and 2017 using the same conditions as above. Amplified products from the second round were electrophorezed in a $2 \%$ agarose gel, stained with ethidium bromide and visualized under ultra-violet light.
HBV DNA quantification - HBV DNA levels in serum were analyzed by the Cobas Amplicor HBV Monitor Test assay (Roche Molecular Systems, Pleasanton, CA, USA) according to the manufacturer's instructions. Briefly, DNA was isolated from $100 \mu \mathrm{L}$ of serum by polyethylene glycol precipitation, followed by virion lysis and neutralization. A known quantity of an internal quantification standard (QS) was introduced into each sample and used throughout the molecular assay. A 104-bp segment of the highly conserved pre-core region was amplified using one biotinylated primer (HBV-104UB) and one non-biotinylated primer (HBV-104D). The QS was amplified with the same primers as target HBV, generating a 104-bp amplicon. The Cobas Amplicor instrument automatically performed PCR amplification, hybridization and detection. According to the manufacturer's package insert, the Cobas Amplicor HBV Monitor test shows linearity from $2.0 \times 10^{2}$ (lower detection limit) to $2.0 \times 10^{5} \mathrm{HBV}$ DNA copies $/ \mathrm{mL}$.

Amplification of surface/DNA polymerase $(S / P)$ and $B C P /$ pre-core/core regions - HBV DNA was extracted from $100 \mu \mathrm{L}$ of serum by the acid guanidinium thiocyanate/phenol/chloroform method (Chomczynski \& Sacchi 1987). A 476-nucleotide fragment (nt 255-731) of the overlapping S/P genes was analyzed to determine the HBV genotype and the presence of drug resistance mutations. This S/P fragment was amplified by nested PCR using a set of primers previously described (Da Silva et al. 2001, Sitnik et al. 2004). Primers FHBS1 and L840 and primers FHBS2 and 3'LAM2 were used for the first and second rounds, respectively. Amplifications were carried out for 35 cycles at $94^{\circ} \mathrm{C}$ for $30 \mathrm{~s}, 56^{\circ} \mathrm{C}$ for $30 \mathrm{~s}$ and $72^{\circ} \mathrm{C}$ for $1 \mathrm{~min}$, with a final extension step of $5 \mathrm{~min}$ at $72^{\circ} \mathrm{C}$.

A 306-nucleotide fragment (nt 1653-1959) of the BCP/ pre-core/core regions was analyzed to identify mutations related to $\mathrm{HBeAg}$ expression and/or viral replication, such as those found in the BCP (A1762T and G1764A) and precore (G1896A and C1899A) regions. The set of primers described by Takahashi et al. (1995) was used and includes the following: primers EP1.1 and EP1.2 for the first round and primers EP2.1 and EP 2 for the second round of PCR. The cycling temperatures were $1 \mathrm{~min}$ at $94^{\circ} \mathrm{C}, 30$ cycles of $30 \mathrm{~s}$ at $94^{\circ} \mathrm{C}, 30 \mathrm{~s}$ at $56^{\circ} \mathrm{C}$ and $40 \mathrm{~s}$ at $72^{\circ} \mathrm{C}$, with a final extension step of $5 \mathrm{~min}$ at $72^{\circ} \mathrm{C}$.

Positive and negative controls were included in each set of reactions. The nested PCR products were electrophorezed in a $2 \%$ agarose gel.

Sequencing - Sequencing was performed with dideoxynucleotides (ddNTPs) and fluorescent markers using the ABI Prism ${ }^{\circledR}$ BigDyeTM Terminator kit (Applied Biosystems, Foster City, CA, USA) with the same primers used in the second round of PCR according to manufacturer's instructions. Samples were sequenced on an Automatic Sequencer ABI Prism 3100 (Applied Biosystems, Foster City, CA, USA). Both sense and antisense strands were analyzed.

Sequence analysis and genotyping - Nucleotide sequences of both regions were validated using the PhredPhrap software and consensus sequences were obtained by alignment of both strands (sense and antisense) using 
the CAP3 DNA sequence assembly programme (Ewing et al. 1998, Ewing \& Green 1998, Huang \& Madan 1999).

Nucleotide sequences were compared with previously reported sequences of the different HBV genotypes (A-H) obtained from GenBank (ncbi.nlm.nih.gov/). Sequences were aligned using CLUSTAL_X (Thompson et al. 1997) and the alignments were visually inspected and edited using BioEdit 7.0.5.3 (Hall 1999).

HBV genotypes were determined by phylogenetic analysis using the distance method (neighbor joining) implemented in Molecular Evolutionary Genetics Analysis (MEGA) software version 4.0 (megasoftware.net/) (Tamura et al. 2007). Robustness of the phylogenetic groups was evaluated using 1,000 bootstrap replicates. MEGA version 4.0 was used to translate the sequences and analyze their amino acid sequences. To identify the mutations in the S/P and BCP/ pre-core/core regions, HBV sequences from this study were compared with a sequence from wild type HBV.

Nucleotide sequence data were deposited in the GenBank database under the following accession: GU968704-GU968714 (BCP/pre-core/core regions) and GU968715-GU968715 (S/P region).
Statistical analysis - Initially, a descriptive analysis of the study variables was performed. The co-infection prevalence rate and the $95 \%$ confidence interval (CI 95\%) were calculated using binomial distribution. To compare the proportion presented in the association tables, Chi-square or Fisher's exact statistic tests were applied (Kirkwood 2003). Regarding age and number of $\mathrm{CD}^{+} \mathrm{T}$ cells in peripheral blood, estimates were made to determine the central tendency and dispersion measurements. We verified that these variables were not normally distributed by evaluation with the nonparametric Kolmogorov-Smirnov test and, therefore, the median within the minimum and maximum values was used. To compare medians, the non-parametric MannWhitney test was used (Wilcoxon sum of ranks test). A significance level of 5\% was considered for all statistical tests. We used Excel to construct tables and figures and Stata (version 9.0) for statistical analysis.

Ethics - The study was approved by the Research Ethical Committee of HC-FMUSP and by the Research Ethical Committee of Instituto Adolfo Lutz.

\section{TABLE I}

Epidemiological, clinical and laboratory results of $59 \mathrm{HBs} A$ g-reactive patients co-infected with human immunodeficiency virus

\begin{tabular}{|c|c|c|}
\hline Demographic and epidemiological variables & $\mathrm{n}$ & $\%$ \\
\hline Males & 58 & 98.3 \\
\hline Age (mean \pm standard deviation) (years) & - & $44.8 \pm 7.2$ \\
\hline Men who have sex with men & 42 & 71.1 \\
\hline Intravenous drug use & 05 & 8.5 \\
\hline Clinical variables & $\mathrm{n}$ & $\%$ \\
\hline Advanced hepatic disease & 10 & 16.9 \\
\hline Non adherence to treatment & 05 & 8.5 \\
\hline Previous antiretrovirals use & 59 & 100 \\
\hline Previous LAM use & 56 & 95 \\
\hline Previous TDF use & 43 & 72.9 \\
\hline Previous ENT use & 04 & 6.8 \\
\hline Previous IFN use & 09 & 15.2 \\
\hline Previous LAM, TDF, ENT or IFN use & 55 & 93.2 \\
\hline Laboratory variables & $\mathrm{n}$ & $\%$ \\
\hline $\mathrm{HBeAg}$ reactivity & 31 & 52.5 (CI 95: 39.1-65.7) \\
\hline Viremia $(\mathrm{HBV} \text { DNA } \geq 60 \mathrm{IU} / \mathrm{mL})^{a}$ & 22 & 37.3 \\
\hline Mean CD4 ${ }^{+}$T-cells count (range) & 538 & $16-1200$ \\
\hline Liver fibrosis presence at histology $\geq 2$ & 14 & 23.7 \\
\hline $\mathrm{ALT}>1.5 \times \mathrm{ULN}$ & 16 & 27 \\
\hline GGT $>1.5 \times$ ULN & 15 & 25.4 \\
\hline $\mathrm{ALP}>1.5 \times \mathrm{ULN}$ & 07 & 11.9 \\
\hline
\end{tabular}

a: quantified by Cobas Amplicor; ALP: alkaline phosphatase ALT: alanine aminotransferase; ENT: entecavir; GGT: gamma-glutamyl transferase; HBV: hepatitis B virus; IFN: interferon; LAM: lamivudine; TDF: tenofovir; ULN: upper limit of normality. 


\section{RESULTS}

Patients - A total of 2,412 patients from the AIDS Outpatient Clinic of the HC-FMUSP with confirmed HIV infection and serological markers for hepatitis B were initially enrolled in our study. Among the 2,412 identified patients, 120 (4.9\%; CI 95\%: 4.2-5.9) were HBsAg-reactive. Only 74 patients actually participated in the study. Of these, 59 remained HBsAg-reactive and were analyzed for HBV DNA quantification and sequencing.

Clinical and epidemiological features - Clinical and epidemiological features of the $59 \mathrm{HBsAg}$-reactive patients are shown in Table I. Among the 59 patients, previous TDF usage ranged from 1-34 months, while for LAM it ranged from 6-96 months.

Characteristics of $\mathrm{HBeAg}$ and the $\mathrm{HBV}$ viral load - Among the 59 HBsAg-reactive patients, 22 (37.3\%) showed positive viremia (HBV DNA) either by in-house nested PCR or by Cobas Amplicor. Among the $59 \mathrm{HB}-$ sAg-reactive patients, 31 were $\mathrm{HBeAg}$-reactive (52.5\%; CI 95\%: 39.1-65.7).

Most $(86.4 \%)$ of the patients with detectable HBV DNA were HBeAg-reactive, while only $10.8 \%$ of the non-reactive $\mathrm{HBeAg}$ patients showed detectable $\mathrm{HBV}$ DNA. We observed a statistically significant $(\mathrm{p}<0.001)$ association between $\mathrm{HBeAg}$ reactivity and positive viremia (HBV DNA) (Table II).

$H B V$ genotypes by phylogenetic analysis of the $S / P$ region and the BCP/pre-core/core regions - Among the 22 patients with detectable HBV DNA, we determined the HBV genotype in 16 patients. The phylogenetic tree analysis (Fig. 1) showed the following genotypes: A: 12 (75\%), D: one $(6.25 \%)$, F: one $(6.25 \%)$ and G: two (12.50\%).

Analysis of the amino acid sequences of the HBsAg coding region from HBV genotype $G$ from patients 6 and 14 is shown in Fig. 2. For patient 14, some polymorphic sites were identified, suggesting that this patient harbored a heterogeneous population of virus.

\section{TABLE II}

Distribution of hepatitis B virus (HBV) according

to $\mathrm{HBeAg}$ seropositivity in patients co-infected with human immunodeficiency virus and HBV

\begin{tabular}{lcc}
\hline & \multicolumn{2}{c}{ HBeAg } \\
\cline { 2 - 3 } Viral load & negative & positive \\
$\mathrm{n}(\%)$ & $\mathrm{n}(\%)$ \\
\hline$<60$ & $25(89.3)$ & $12(38.7)$ \\
$60-999$ & $1(3.6)$ & $7(22.6)$ \\
$1,000-1,999$ & $1(3.6)$ & $1(3.2)$ \\
$2,000-19,999$ & $1(3.6)$ & $1(3.2)$ \\
20,000 & - & $10(32.3)$ \\
Total & $28(100)$ & $31(100)$ \\
\hline
\end{tabular}

$\mathrm{p}<0.001$.
The sequence analysis of the $\mathrm{BCP} /$ pre-core/core regions is shown in Table III. We observed the presence of two BCP mutations, A1762T and G1764A, in two patients and only G1764A in another two. Only one patient also showed a pre-core G1896A mutation. This was the only genotype D case in our study population.

A good quality sequence for the $\mathrm{BCP} /$ pre-core/core regions was not obtained for patient 14 . These regions show the hallmark characteristics of genotype $G$ (translational stop codons at amino acids 2 and 28 of the pre-core region and a 12 amino acid insert in the amino-terminal part of the $\mathrm{HBcAg}$ ). The low quality sequence could be explained by the fact that this patient harbored both $\mathrm{A}$ and $\mathrm{G}$ genotypes due to the insertion characteristic of genotype $G$ present in some of the circulating viruses.

For patient 6 , the $\mathrm{S} / \mathrm{P}$ sequence was associated with other genotype $\mathrm{G}$ sequences in the phylogenetic tree, but the $\mathrm{BCP} /$ pre-core/core region sequence was characteristic of HBV genotype A and did not show any of the genotype $\mathrm{G}$ hallmarks.

$H B V$ mutations in the $S / P$ region - Mutations found in the surface and polymerase genes are also shown in Table III. A mutation at codon 204 of the reverse transcriptase of the HBV polymerase gene was observed; nine patients had a methionine-to-valine substitution (rtM204V) and one had a methionine-to-isoleucine substitution (rtM204I). All of these patients also had an as-

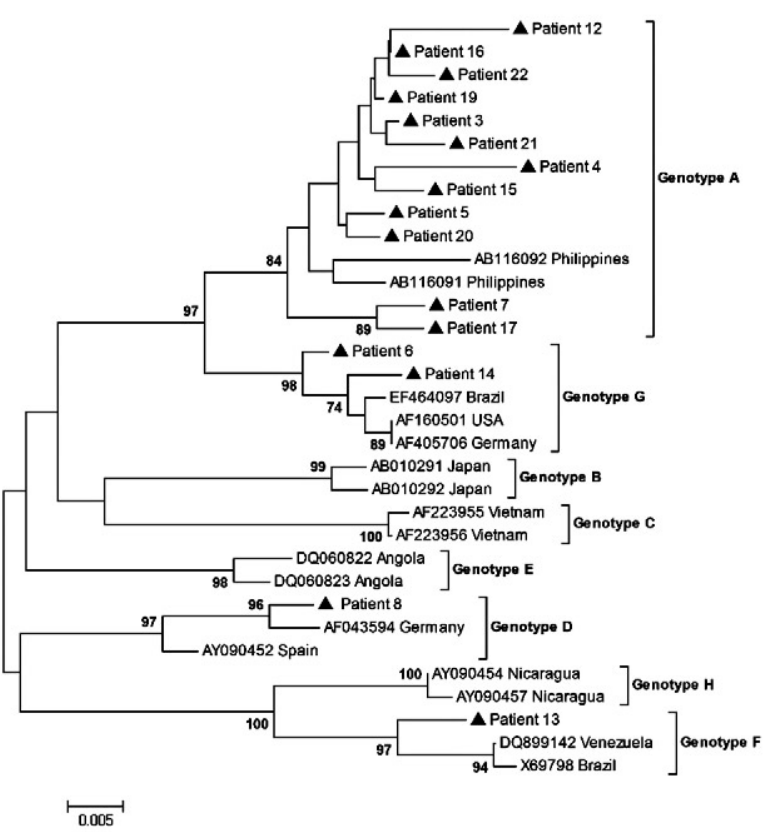

Fig. 1: phylogenetic tree of hepatitis B virus (HBV) surface/DNA polymerase $(\mathrm{S} / \mathrm{P})$ region. Neighbor joining analysis was carried out with other sequences from different HBV genotypes previously described using MEGA4 software. Sequences obtained from this study are marked with black triangles and those obtained from the GenBank are designated by their accession number followed by the country of origin. Bootstrap values obtained with 1,000 replicates are shown in the nodes (only values $>70 \%$ are shown). Genotypes are indicated at the corresponding tree branches. 


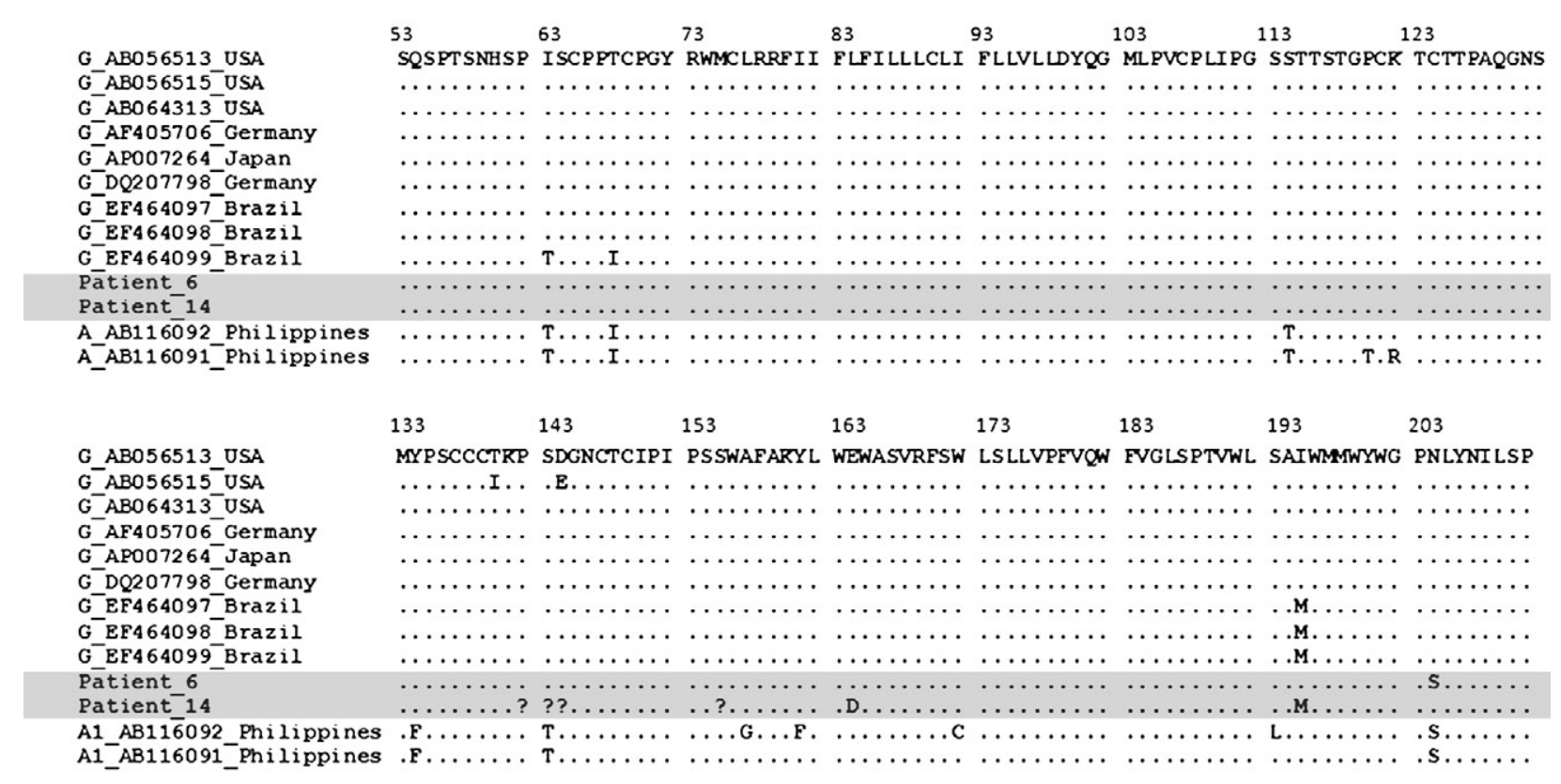

Fig. 2: amino acid sequences from partial nucleotide sequence of HBsAg (S) gene from two hepatitis B virus (HBV) genotype G in HBV/ human immunodeficiency virus co-infected Brazilian patients (shown in the grey box) and from other HBV genotype G and A sequences previously reported, retrieved from GenBank. Interrogation marks in patient 14 indicate ambiguities in nucleotide sequence representing characteristics of both genotypes ( $G$ and A). Dashes indicate identity to the sequence AB056513 and changed amino acids are indicated by the appropriate single letter code.

sociated leucine-to-methionine substitution at position 180 (rtL180M). Along with the rtL180M and rtM204V mutations, three patients also showed a leucine-to-valine substitution (rtL80V) and two patients had a valine-toleucine substitution (rtV173L) in the polymerase gene.

Some mutations in the HBV polymerase region implied changes in the following envelope HBsAg gene codons: sI195M (7 patients), sI195M/sE164D (2 patients) and sW196L (1 patient).

Association between HBV genotypes and selected variables - To analyze the association between HBV genotypes and selected variables, we separated the patients into "genotype A" and "non-genotype A" groups because of the small number of cases and low representation of the other genotypes. We did not observe any statistically significant associations between HBV genotypes and the selected clinical or epidemiological variables.

Association between mutations in the HBV polymerase region and selected variables - The only observed association with statistical significance occurred between the presence of HBV mutations and use of LAM $(p=0.04)$. However, statistically significant associations were not observed when the presence or absence of mutations in the polymerase region was compared to other clinical or epidemiological variables.

\section{DISCUSSION}

The development of resistance to antiviral medications is a great challenge for the treatment of hepatitis B. In our study, the presence of mutations in the HBV genome associated with LAM-resistance was observed in 10 of the 22 patients with detectable viremia. Among these, all were using LAM and seven were also using TDF. The duration of TDF usage varied from 1-34 months, while the use of LAM ranged from 6-96 months.

TDF and LAM are highly effective medications for decreasing HBV viremia in patients infected only with HBV (Marcellin et al. 2008) and in patients co-infected with HIV (Matthews et al. 2008). Nevertheless, in patients already using LAM, the use of TDF can eventually lead to a slower decrease in HBV viremia. In some cases, viral DNA can still be detected for longer periods, sometimes even after 24 months of continued therapy with both medications (Lada et al. 2008, Tuma et al. 2008). This fact probably explains the presence of detectable levels of HBV in patients using LAM and TDF because all patients using TDF had a prolonged use of LAM monotherapy.

Another possible explanation for the persistence of HBV viremia in our study population is the non-adherence to the prescribed medications. For instance, we observed that five of the 59 patients included were not conforming to the antiviral treatment regimen as recommended in their prescriptions.

Considering the mutations observed in the reverse transcriptase region of the polymerase gene, rtM204V was found in nine patients while rtM204I was found in only one patient. This patient with rtM204I also showed the rtL180M mutation and the sW196L mutation in the HBsAg overlapping gene. There were three identified mutation patterns in the rtM204V mutation: $\mathrm{rtL} 180 \mathrm{M}+$ rtM204V (1 patient), rtL180M + rtT184S/L + rtM204V (3 patients), rtL80V + rtL180M + rtM204V (3 patients) 


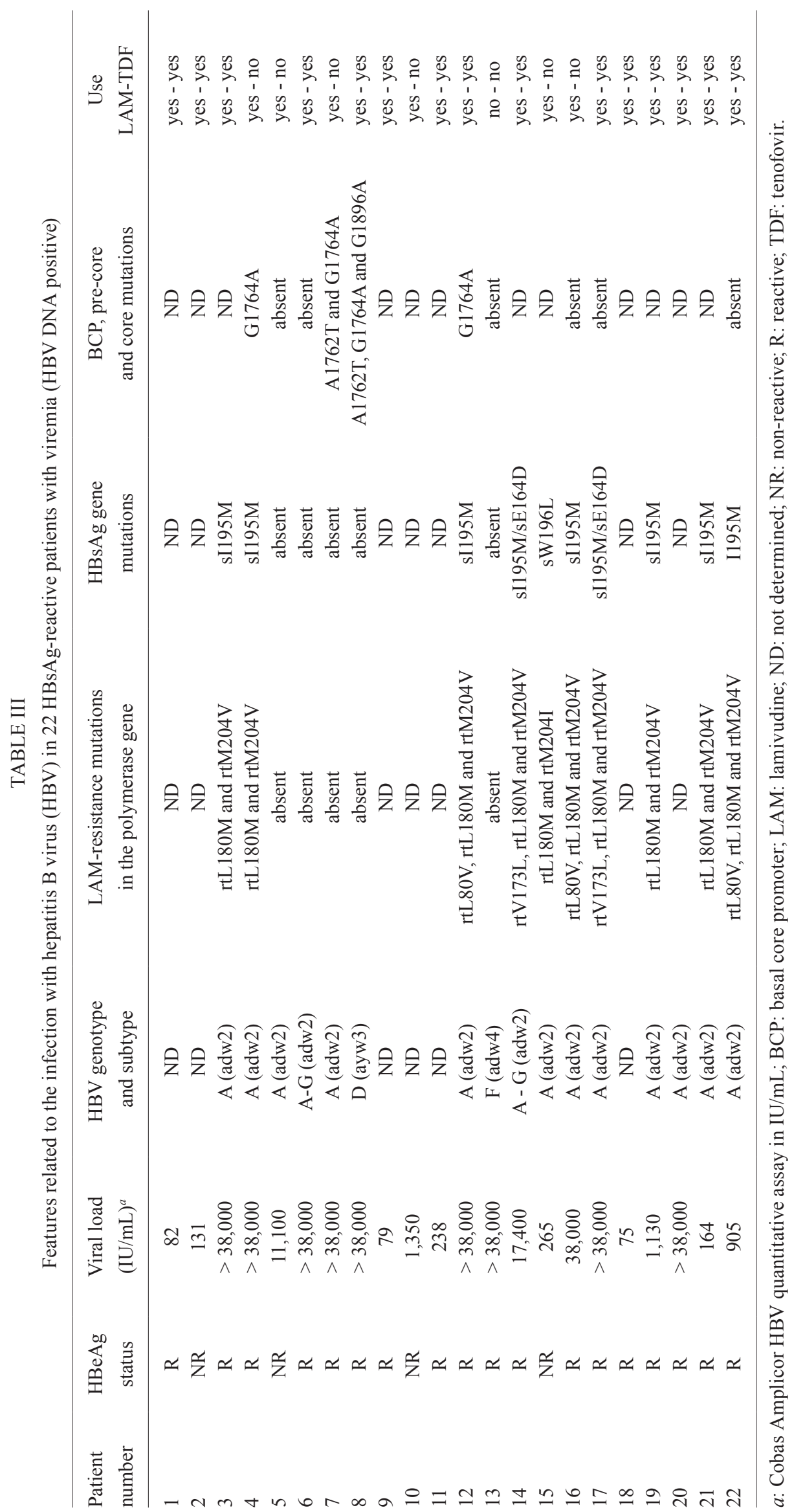


and rtV173L + rtL180M + rtM204V (2 patients). The sI195M mutation in the HBsAg surface gene reading frame, which is associated with rtL180M, was present in all patients. More importantly, it is known that the mutation pattern, rtV173L + rtL180M + rtM204V (seen in 2 patients), is associated with sE164D + sI195M in the HBsAg gene (Torresi et al. 2002). HBV strains carrying these mutations have a reduced capability to bind to HBsAg antibodies (anti-HBs) in vitro. This feature is shared with the classical vaccine-escape strain (harboring mutation sG145R) (Torresi et al. 2002). We do not know whether the HBV strains that showed decreased antigenicity could escape the neutralizing action of the anti-HBs antibodies induced by vaccination and cause infection in previously vaccinated individuals (Torresi et al. 2002, Matthews et al. 2006).

Various studies in HBV-HIV co-infected patient populations have evaluated the presence and clinical importance of these mutations (Matthews et al. 2006, Soriano et al. 2008), but in Brazil few studies have evaluated this matter (Santos et al. 2004, Sucupira et al. 2006, Bottecchia et al. 2008, Mendes-Correa et al. 2008). If these mutations are indeed associated with vaccine escape, they would have an important impact on public health. Indeed, larger and additional population studies are needed to evaluate the presence of these mutations and their ability to spread in the general population or in high-risk groups, especially in immunocompromised patients, such as HIV-positive individuals.

It is noteworthy that the four patients in our population who showed BCP and/or pre-core mutations were HBeAg-reactive. This mutation pattern is commonly observed in HBeAg-non-reactive patients. This finding could indicate that these patients probably have some minor viral strains that are not mutated in this region and thus maintain the $\mathrm{HBeAg-reactive} \mathrm{status.}$

In our sample population, most of the patients with detectable HBV DNA (86.4\%) were HBeAg-reactive. Most of them were males who had sex with multiple male partners without protection. Our data also showed association between $\mathrm{HBeAg}$ reactivity and $\mathrm{HBV}$ viremia above $20.000 \mathrm{IU} / \mathrm{mL}(\mathrm{p}<0.001)$. These results are in accordance with similar results found in patients infected with HBV only (Lok \& McMahon 2009) and a few groups have evaluated this finding among HIV co-infected patients (Soriano et al. 2008, Matthews et al. 2009). These data are relevant for the studied population and have practical importance, especially in instances where the determination of the HBV viral load is not available.

We were able to determine the HBV genotypes in 16 of the patients with detectable HBV viremia. Among them, the HBV genotype distribution was as follows: A $(\mathrm{n}=12 ; 75 \%), \mathrm{G}(\mathrm{n}=2 ; 13 \%), \mathrm{D}(\mathrm{n}=1 ; 6 \%)$ and $\mathrm{F}(\mathrm{n}=$ $1 ; 6 \%$ ). In relation to the identified genotypes, it is important to stress that the predominance of genotype A in this population should be carefully analyzed. We can only conclude that among the patients with detectable viremia, genotype A was predominant. It is possible that other genotypes predominate among the patients whose genotypes we were unable to determine.
In Brazil, the presence of genotype $\mathrm{G}$ has been rarely seen (Lobato et al. 2006, Bottecchia et al. 2008, Mendes-Correa et al. 2008). Bottecchia et al. (2008) identified genotype $\mathrm{G}$ in a patient infected with HBV only and in two patients co-infected with HIV. The current study is the second to identify the genotype among HIV co-infected patients. The presence of genotype $\mathrm{G}$ has been associated by some authors with a history of homosexual transmission among males (Sánchez et al. 2007). The two patients in our study with this genotype were homosexual males, which supports the hypothesis that the transmission of HBV-G could somehow be associated with this sexual behavior. Additional studies with larger sample populations that analyze HBV genotypes in partners with different sexual behaviors are needed to demonstrate this association.

HBV genotype $G$ has been associated with the presence of two stop codons in the pre-core region, which could prevent HBeAg production (Kato et al. 2002). The two infected patients with genotype $\mathrm{G}$ were positive for $\mathrm{HBeAg}$, but as genotype $\mathrm{G}$ does not produce this antigen, a co-infection with another genotype is possible.

Our sequence data strongly suggest co-infection with genotype A or infection with a recombinant virus between genotypes $\mathrm{A}$ and $\mathrm{G}$. For patient 6 , the S/P sequence was clearly associated with other genotype $\mathrm{G}$ sequences in the phylogenetic tree. The $\mathrm{BCP} /$ pre-core/core region sequence was characteristic of HBV genotype A and did not show any of the genotype $\mathrm{G}$ hallmarks. For patient 14, we found the presence of two peaks in the chromatogram at some positions, meaning that two different nucleotides were found. Such ambiguities do not indicate background in the chromatograms, as they had good quality according to the Phred Phrap programme. To fully resolve this question, cloning, end point dilution PCR or specific PCR to detect HBV genotypes would have to be performed.

The BCP mutations, A1762T and G1764A, were found in two patients and the G1764A mutation only in another two. Only one patient showed a pre-core G1896A mutation. This was the only patient with genotype $\mathrm{D}$ in our study group; pre-core mutations are more frequent in this genotype. Interestingly, all of these patients were HBeAg-reactive.

Nonetheless, our study presents some limitations. First, it was a cross-sectional study, which did not permit serial analysis of the samples or demonstration of the evolutionary emergence of mutations. Second, it was not possible to evaluate the presence of these mutations in all patients, particularly before antiviral therapy usage. Finally, the lack of association between mutations and genotypes observed in this study may be due to the small number of patients studied.

In conclusion, among patients co-infected with HIV and HBV under antiviral treatment, a high prevalence of mutations associated with LAM-resistance was observed in the DNA polymerase gene of HBV. Some mutations linked to vaccine escape mutations were found in the HBsAg coding gene, which could have an impact on public health if confirmed further. An association 
between the presence of $\mathrm{HBeAg}$ and a high viral load for $\mathrm{HBV}$ was also observed. The genotype $\mathrm{G}$, which is rarely seen in Brazil, was also found in two patients, with strong serological and molecular data suggesting co-infection or recombination with genotype A.

\section{REFERENCES}

Benhamou Y 2007. Hepatitis B in the HIV-coinfected patient. $J$ Acquir Immune Defic Syndr 45 (Suppl. 2): S57-65.

Benhamou Y, Bochet M, Thibault V, Di Martino V, Caumes E, Bricaire F, Opolon P, Katlama C, Poynard T 1999. Long-term incidence of hepatitis B virus resistance to lamivudine in human immunodeficiency virus-infected patients. Hepatology 30: 1302-1306.

Bonacini M, Louie S, Bzowej N, Wohl AR 2004. Survival in patients with HIV infection and viral hepatitis B or C: a cohort study. AIDS 18: 2039-2045.

Bottecchia M, Souto FJ, O KM, Amendola M, Brandão CE, Niel C, Gomes SA 2008. Hepatitis B virus genotypes and resistance mutations in patients under long term lamivudine therapy: characterization of genotype $\mathrm{G}$ in Brazil. BMC Microbiol 22: 8-11.

Braga WS, Brasil LM, de Souza RA, Castilho M da C, da Fonseca JC 2001. The occurrence of hepatitis B and delta virus infection within seven Amerindian ethnic groups in the Brazilian western Amazon. Rev Soc Bras Med Trop 34: 349-355.

Braga WS, Silva EB, Souza RA, Tosta CE 2005. Seroprevalence of hepatitis B and malaria infection in Lábrea, Brazilian western Amazon: estimates of coinfection rates. Rev Soc Bras Med Trop 38: 218-223.

Chomczynski P, Sacchi N 1987. Single-step method of RNA isolation by acid guanidinium thiocyanate-phenol-chloroform extraction. Anal Biochem 162: 156-159.

Da Silva LC, Pinho JR, Sitnik R, Da Fonseca LE, Carrilho FJ 2001. Efficacy and tolerability of long-term therapy using high lamivudine doses for the treatment of chronic hepatitis B. J Gastroenterol 36: 476-485.

Ewing B, Green P 1998. Base-calling of automated sequencer traces using phred. II. Error probabilities. Genome Res 8: 186-194.

Ewing B, Hillier L, Wendl MC, Green P 1998. Base-calling of automated sequencer traces using phred I. Accuracy assessment. Genome Res 8: 175-185.

Focaccia R, da Conceição OJ, Sette H Jr, Sabino E, Bassit L, Nitrini DR, Lomar AV, Lorenço R, Vieira De Souza F, Kiffer CR, Santos EB, Gonzales MP, Sáez-Alquézar A, Riscal JR, Fischer D 1998. Estimated prevalence of viral hepatitis in the general population of the municipality of São Paulo, measured by a serologic survey of a stratified, randomized and residence-based population. Braz $J$ Infect Dis 2: 269-284.

Hall TA 1999. BioEdit: a user-friendly biological sequence alignment editor and analysis program for Windows 95/98/NT. Nucl Acids Symp Ser 41: 95-98.

Huang X, Madan A 1999. CAP3: a DNA sequence assembly program. Genome Res 9: 868-877.

Kato H, Orito E, Gish RG, Sugauchi F, Suzuki S, Ueda R, Miyakawa Y, Mizokami M 2002. Characteristics of hepatitis B virus isolates of genotype $\mathrm{G}$ and their phylogenetic differences from the other six genotypes (A through F). J Virol 76: 6131-6137.

Kirkwood BR 2003. Univariate analysis and chi-square test. In BR Kirkwood, JAC Sterne, Essential medical statistics, Blackwell Science, Malden, $501 \mathrm{pp}$.

Lada O, Gervais A, Branger M, Peytavin G, Collin G, Fraqueiro G,
Moucari R, Males S, Martinot-Peignoux M, Matheron S, Marcellin P 2008. De novo combination therapy of tenofovir disoproxil fumarate (TDF) plus lamivudine (LAM) or TDF plus emtricitabine (FTC) is associated with early virologic response in $\mathrm{HIV} / \mathrm{HBV}$ co-infected patients. Hepatology 48: 720A.

Lobato C, Tavares-Neto J, Rios-Leite M, Trepo C, Vitvitski L, Parvaz P, Zoulim F, D’Oliveira A Jr, Paraná R 2006. Intrafamilial prevalence of hepatitis B virus in Western Brazilian Amazon Region: epidemiologic and biomolecular study. $J$ Gastroenterol Hepatol 21: $863-868$

Lok AS, McMahon BJ 2009. Chronic hepatitis B: update 2009. Hepatology 50: 661-662.

Marcellin P, Heathcote EJ, Buti M, Gane E, de Man RA, Krastev Z, Germanidis G, Lee SS, Flisiak R, Kaita K, Manns M, Kotzev I, Tchernev K, Buggisch P, Weilert F, Kurdas OO, Shiffman ML, Trinh H, Washington MK, Sorbel J, Anderson J, Snow-Lampart A, Mondou E, Quinn J, Rousseau F 2008. Tenofovir disoproxil fumarate versus adefovir dipivoxil for chronic hepatitis B. NEngl JMed 359: 2442-2455.

Matthews GV, Avihingsanon A, Lewin SR, Amin J, Rerknimitr R, Petcharapirat P, Marks P, Sasadeusz J, Cooper DA, Bowden S, Locarnini S, Ruxrungtham K, Dore GJ 2008. A randomized trial of combination hepatitis B therapy in HIV/HBV coinfected antiretroviral naïve individuals in Thailand. Hepatology 48: 1062-1069.

Matthews GV, Bartholomeusz A, Locarnini S, Ayres A, Sasaduesz J, Seaberg E, Cooper DA, Lewin S, Dore GJ, Thio CL 2006. Characteristics of drug resistant $\mathrm{HBV}$ in an international collaborative study of HIV-HBV-infected individuals on extended lamivudine therapy. AIDS 20: 863-870.

Matthews GV, Seaberg E, Dore GJ, Bowden S, Lewin SR, SasadeusZ J, Marks P, Goodman Z, Philp FH, Tang Y, Locarnini S, Thio CL 2009. Combination HBV therapy is linked to greater HBV DNA suppression in a cohort of lamivudine-experienced HIV/ HBV coinfected individuals. AIDS 23: 1707-1715.

Mendes-Correa MC, Barone AA, Cavalheiro N, Tengan FM, Guastini C 2000. Prevalence of hepatitis B and C in the sera of patients with HIV infection in São Paulo, Brazil. Rev Inst Med Trop Sao Paulo 42: 81-85.

Mendes-Correa MC, Pinho JR, Leite OM, Martins LG, Leite AG, Silva MH, Sitnik R, Uip DE 2008. Hepatitis B genotype distribution and high frequency of lamivudine resistance mutations in Brazilian HIV/hepatitis B virus co-infected patients. Hepatology 48: 538A.

Monteiro MR, do Nascimento MM, Passos AD, Figueiredo JF 2004. Soroepidemiological survey of hepatitis B virus among HIV/ AIDS patients in Belém, Pará-Brasil. Rev Soc Bras Med Trop 37 (Suppl. 2): 27-32.

Pereira LM, Martelli CM, Merchán-Hamann E, Montarroyos UR, Braga MC, de Lima ML, Cardoso MR, Turchi MD, Costa MA, de Alencar LC, Moreira RC, Figueiredo GM, Ximenes RA 2009. Population-based multicentric survey of hepatitis B infection and risk factor differences among three regions in Brazil. Am J Trop Med Hyg 81: 240-247.

Pinho JR, Santos CA, Gonzalez CL, Bassit L, Barreto CC, SaezAlquezar A, França AV, Carrilho FJ, Fonseca LE, Chamone DA, da Silva LC 1993. Detection of hepatitis B virus DNA by the polymerase chain reaction in anti-HBe positive chronic hepatitis B patients. Rev Inst Med Trop Sao Paulo 35: 515-520.

Portelinha Filho AM, do Nascimento CU, Tannouri TN, Troiani C, Ascêncio EL, Bonfim R, D'Andrea LAZ, Prestes-Carneiro LE 2009. Seroprevalence of HBV, HCV and HIV co-infection in selected individuals from state of São Paulo, Brazil. Mem Inst Oswaldo Cruz 104: 960-963. 
Sánchez LV, Tanaka Y, Maldonado M, Mizokami M, Panduro A 2007. Difference of hepatitis B virus genotype distribution in two groups of Mexican patients with different risk factors. High prevalence of genotype $\mathrm{H}$ and $\mathrm{G}$. Intervirology 50: 9-15.

Santos EA, Sucupira MV, Arabe J, Gomes SA 2004. Hepatitis B virus variants in an HIV-HBV co-infected patient at different periods of antiretroviral treatment with and without lamivudine. $B M C$ Infect Dis 4: 29.

Shepard CW, Simard EP, Finelli L, Fiore AE, Bell BP 2006. Hepatitis $\mathrm{B}$ virus infection: epidemiology and vaccination. Epidemiol Rev 28: $112-125$.

Sitnik R, Pinho JR, Bertolini DA, Bernardini AP, Da Silva LC, Carrilho FJ 2004. Hepatitis B virus genotypes and precore and core mutants in Brazilian patients. J Clin Microbiol 42: 2455-2460.

Soriano V, Puoti M, Peters M, Benhamou Y, Sulkowski M, Zoulim F, Mauss S, Rockstroh J 2008. Care of HIV patients with chronic hepatitis B: updated recommendations from the HIV-Hepatitis B Virus International Panel. AIDS 22: 1399-1410.

Soriano V, Tuma P, Vispo E, Labarga P, Fernández JV, Medrano J, Barreiro P 2009. Hepatitis B in HIV patients: what is the current treatment and what are the challenges? J HIV Ther 14: 13-18.

Souza MG, Passos AD, Machado AA, Figueiredo JF, Esmeraldino LE 2004. HIV and hepatitis B virus co-infection: prevalence and risk factors. Rev Soc Bras Med Trop 37: 391-395.

Sucupira MVF, Mello FCA, Santos EA, Niel C, Rolla VC, Arabe J, Gomes SA 2006. Patterns of hepatitis B virus infection in Brazilian human immunodeficiency virus infected patients: high prevalence of occult infection and low frequency of lamivudine resistant mutations. Mem Inst Oswaldo Cruz 101: 655-660.

Takahashi K, Aoyama K, Ohno N, Iwata K, Akahane Y, Baba K,
Yoshizawa H, Mishiro S 1995. The precore/core promoter mutant (T1762A1764) of hepatitis B virus: clinical significance and an easy method for detection. J Gen Virol 76: 3159-3164.

Tamura K, Dudley J, Nei M, Kumar S 2007. MEGA4: Molecular Evolutionary Genetics Analysis (MEGA) software version 4.0. $\mathrm{Mol}$ Biol Evol 24: 1596-1599.

Tavares-Neto J, Almeida D, Soares MC, Uchoa R, Viana S, Darub R, Farias E, Rocha G, Vitvitski L, Paraná R 2004. Seroprevalence of hepatitis $\mathrm{B}$ and $\mathrm{C}$ in the Western Brazilian Amazon Region (Rio Branco, Acre): a pilot study carried out during a hepatitis B vaccination program. Braz J Infect Dis 8: 133-139.

Thompson JD, Gibson TJ, Plewniak F, Jeanmougin F, Higgins DG 1997. The CLUSTAL_X Windows interface: flexible strategies for multiple sequence alignment aided by quality analysis tools. Nucleic Acids Res 25: 4876-4882.

Torresi J 2002. The virological and clinical significance of mutations in the overlapping envelope and polymerase genes of hepatitis B virus. J Clin Virol 25: 97-106.

Tovo CV, Dos Santos DE, de Mattos AZ, de Almeida PR, de Mattos AA, Santos BR 2006. Ambulatorial prevalence of hepatitis B and $\mathrm{C}$ markers in patients with human immunodeficiency virus infection in a general hospital. Arq Gastroenterol 43: 73-76.

Tuma P, Bottecchia M, Sheldon J, Medrano J, Vispo E, Madejón A, Martin-Carbonero L, Barreiro P, Soriano V 2008. Prior lamivudine (LAM) failure may delay time to complete HBV-DNA suppression in HIV patients treated with tenofovir plus LAM. Hepatology 48: 740A.

Zago AM, Machado TF, Cazarim FL, Miranda AE 2007. Prevalence and risk factors for chronic hepatitis B in HIV patients attended at a sexually-transmitted disease clinic in Vitória, Brazil. Braz J Infect Dis 11: 475-478. 